\title{
Experiences of Applying GIS for Regional Development Planning
}

\author{
Dr. K.E. Seetharam (Nippon Koei Co. Ltd.) \\ Dr. R.V. Sundaram (Nippon Koei Co. Ltd.)
}

\begin{abstract}
Usefulness and applicability of GIS for regional development planning studies of GIS are discussed with specific reference to two project case studies in developing countries involving large spatial databases. GIS was applied in a water resources master plan study of Kenya for determining land suitability for crops, and for determining areas of groundwater availability. In another regional planning study in Northeast Thailand, GIS was used for land use planning and for environmental planning. It was determined that the powerful inherent capacity of GIS as a Information Management Tool resulted in considerable savings of man-months. Display and manipulation of large spatial databases is also greatly facilitated by a GIS based approach which by conventional methods would have been difficult and very time consuming. The use of GIS for analysis also resulted in the evolution of a valuable digital natural resource database of immense value for planners in the concemed developing countries for future use and updating. For the development of a GIS, parameters such as the scale of base maps and detail of information input into the database were determined to be more important than the choice of computer hardware and software. Interaction among domain experts and the GIS expert as well as educating domain experts about GIS is very important for successful GIS implementation. Training and technology transfer issues need to be considered at an early stage when use of GIS itself is being considered.
\end{abstract}

\section{INTRODUCTION}

The multi-sectoral nature of regional planning and overlap of data needs of various sectors along with the inherent spatial dimension of any planning activity, make the use of GIS as a planning tool very attractive [1],[3]. The simultaneous use of GIS for the integrated planning of various sectors within the framework of a regional development plan also results in the creation of a comprehensive database. This is of immense value in the future for frequent updating of maps and attribute data, and quick generation of planning alternatives and scenarios. Any development project in regional planning and management requires the handling of huge volumes of spatial data and extensive spatial analysis. The enormous amounts of spatial data (such as maps and drawings) to represent natural resources information such as rivers, forest cover, landuse, houses, utility facilities can be efficiently input, stored and managed in an intelligent data base. Over the last five years, Nippon Koei (NK) has executed more than 630 projects in more than 57 developing countries in the world. The applications cover all major engineering fields.
By researching on the GIS based approach NK has learnt about the possibilities for application of cost-effective procedures for data collection, preliminary analysis, selection of alternatives and monitoring to yield best results in projects.

\section{GIS APPLICATION IN PROJECTS}

In this section, typical sectoral applications of GIS in regional development planning are enumerated focussing specifically on two regional development projects namely a "Water Resources Master Plan Study of Kenya" and a "Regional Development Master Plan Study of Northeast Thailand".

\section{Choice of GIS Implementation}

The complexity of manipulating spatial information is the major factor in deciding on GIS implementation. This complexity is dependent on several factors and in most cases can be only estimated based on experience. From the experience in several projects [2], the authors define that the volume of information which is decided by the extent of maps and details of maps largely influences the complexity. Depending on 
the availability of resources in terms of time, man power, money and expertise in a particular project, the value of implementing GIS can be conceptually assessed against the cost for hardware, software and data preparation and the value of final output, as shown in Table 1. The Kenya Water Resources Master Plan Study area is about 600,000 sq. $\mathrm{km}$ while the Thailand Regional Development Plan Study area is about 90,000 sq. $\mathrm{km}$. From Table 1, it is clear that considering the evaluation criteria of cost of data preparation, time and easiness of analysis, and value of final output for such a large development area, the use of GIS seems justified for either project. The large size of the spatial database that was necessary to be created and the immense value in the future for regular updating of spatial and attribute data as well as for use in planning were determined as strong reasons to justify the use of GIS. It was determined that the GIS database in the Kenya study consisted of over 25 layers amounting to over $1500 \mathrm{MB}$ of digital data, while in case of the Thailand study, the database had over 12 layers with over $200 \mathrm{MB}$ of digital data.

\section{Project characteristics}

Table 2 summarizes some of the chief characteristics related to the use of GIS in both the studies. Although a comprehensive database was planned and created, the time frame of the project necessitated the restriction in the application of GIS for planning in the sectors of landuse, agriculture, environment and water. The kind of data available (base maps, analytical theme maps like land suitability maps) as well as budgetary considerations influenced the choice of hardware and software for the GIS system implemented. Table 3 presents a comparison of the input data coverages along with their scales. There is considerable variation in the scales at which different data coverages were input and this was a important factor in determining an appropriate output scale for analyzed data.

\section{Kenya Water Resources Study}

Some of the important analysis requirements in Water Resources Planning concern the availability of suitable land and water for the demand in terms of water requirements for drinking, irrigation and other uses. Here we consider land suitability analysis for crops and groundwater potential analysis.

\section{Land Suitability for Crops}

The land suitability for crops is determined by factors such as soil properties (depth, sodicity, fertility, etc.), slope, landuse, temperature, and humidity. At any particular location, the suitability for the cultivation of a particular crop can be decided if these values are known.

\section{GIS Procedure}

In the GIS terminology, first the map layer for each factor must be created. Then, these must be combined by the polygon-overlay tool. This will yield a new layer where each location has the information on all the factors in the original layers. Now, the criteria for each crop can be applied to select the areas suitable for that crop. The results yield a new layer where the areas suitable and not suitable are marked. Here, the slope information may not be readily available. The elevation data from contours can be modeled using typically say the Triangulated Irregular Network/(TIN) software module in ARC/INFO software and the map can be classified based on slope values. The GIS approach yields results of very high accuracy since the shapes of areas in the original layers are maintained in the analysis.

In typical manual approaches, the layers must be first approximated into grids where the size and location of each cell unit must match for every layer. This process and the subsequent overlay is also very difficult to perform and check against errors, especially when the size of the grid decreases.

\section{Data preparation}

In this study, land suitability analysis was performed for 14 different crops. Land suitability was decided by factors such as soil properties (depth, sodicity, fertility, etc.), temperature, humidity, and slope. The soil boundaries and the soil properties were input in the GIS database. The soil was classified based on the criteria such as soil fertility, etc. and this yielded 390 different soil 
types. The agro-ecological zone map is defined by humidity and temperature information at any location [4]. To create this map, the contours of annual mean rainfall and annual potential evaporation were first digitized. Then they were combined by a polygon-overlay to classify the areas based on the moisture availability. Then the contours of annual mean temperature were digitized and combined to create the map of agro-ecological zones. The classification of areas based on slope was automatically performed using GIS Techniques. First, the model using the Triangulated Irregular Network (TIN) module in ARCINFO GIS software was developed from contours. Then using GIS techniques, a slope map layer was automatically developed. Thus, all the base maps were input in the GIS for the entire area of more than $600,000 \mathrm{sq}$. $\mathrm{km}$. The volume of information can be represented by the number of polygons in each layer: Soll boundaries: 7000 , Agro-ecological zones: 2000, Slope: 1500, Forest: 200, Land Control: 200.

Land Capability Analysis

The layers for soil, landuse, temperature, humidity, and slope were combined by the polygon-overlay technique. The criteria for soil properties, landuse, temperature, humidity and slope were applied to select the suitable areas for the different crops. The areas were ranked as highly suitable (S1), moderately suitable (S2), marginally suitable (S3) and unsuitable (NS). Now the results can be visually seen on the computer terminal as a map. By combining the result layer with the administrative boundaries, the suitable area in each administrative district can be obtained as a table. Similarly, by combining the result layer with the basin boundaries, the suitable area in each basin can be obtained as a table. The maps were produced for 14 different crops - namely, beans, coffee, cotton, culture, fodder, maize potato, pyrethrum, rice, sisal, sorghum, sugarcane, tea, and wheat.

Groundwater Analysis

Groundwater information from the borehole surveys are obtained in the form of tables. There are usually several thousands of records which will have to be accurately input in a database for analysis. Water quality information, such as levels of Sodium, Calcium, Chloride, and pH scale, are available in the form of tables. Usually experts would draw contours on the maps to identify areas of different levels of quality for each parameter. However, with large data volumes, it is quite difficult to draw contours manually.

\section{GIS Database for Boreholes}

The GIS approach was applied to manage more than 7000 records on boreholes which were spread all over the project area in the study. To perform easy checks on the input data, the records were geographically coded using the latitude and longitude information of each borehole. This was quickly registered as a layer in the GIS with other layers like basin boundaries. So it was possible to check for example, the basin number and map sheet number in each borchole by actually viewing the overlay of the basin map and map sheet boundaries in the display. Other rigorous checks for consistency were also performed on the data and these were spatially displayed for checking by experts. The boreholes were classified based on the geology conditions at their location using GIS techniques. The point-in-polygon tool was used between the borehole layer and geology layer to obtain for each borehole the geological situation in its location.

\section{Water Quality Contours}

Here GIS tools were used to enhance the process. For example, to draw contours for levels of electrical conductivity (EC), first the boreholes with EC test data were mapped out. Then, a spatial model using TIN was developed using the EC level at each point. Then contours were automatically developed after considering smoothing for errors. Water quality levels are not spatially continuous like elevation. The levels vary depending on the geological conditions as well. So it was required to perform the TIN model for homogeneous areas with respect to geology and then combine the results to get accurate contours representing the distribution of water quality levels. To achieve this, the boreholes were classified based on geology by performing the point-in-polygon operation with the geology layer. Areas of Groundwater Availability

After developing the layers for the contours for 
each water quality index, the land was classified based on acceptable levels of each index for irrigation. Suitable areas with respect to each factor were selected using GIS techniques. Overlay of these maps is the map showing areas with comprehensively suitable groundwater for irrigation.

\section{Northeast Thailand Regional Planning Study} In a regional planning study, the zoning of land for development and environmental conservation are some major concerns. A description of how GIS was used for land use planning and environmental management is enumerated below:

\section{Land Use Planning}

Determination of the land use development zoning keeping in view the various dimensions of land use policy namely economic (how to make the best use of land), social (land tenure, ownership and allocation), environmental conservation (protected forests, watershed areas, environmentally sensitive areas) and security (international and regional borders), is central to any regional planning activity. Existing land use needs to be compared to land capability and land use development zones need to be determined as per the governing land use policies.

\section{Data Preparation}

High resolution Landsat TM and SPOT satellite imagery at 1:125,000 and 1:100,000 scale respectively was visually interpreted and then digitized and brought into the GIS. The data was projected, transformed into an appropriate coordinate system, edge matched and corrected. Land use potential data (land suitability based on climate, rainfall, soil type and topography) available as paper copy maps was digitized and incorporated into the GIS.

\section{GIS Procedure}

Table 4 outlines the procedure using GIS for determining appropriate land use zoning. Present land use is compared with potential land use in each province (a typical planning unit), and a reclassification done into five broad land use development categories enumerated below:

\section{(a) Protected area}

From existing land use, all existing natural forest areas and water bodies, irrespective of the potential land use are classified under this area. Typically, a percentage of the total area of a region will be set aside for protection which may include existing forest area, watershed areas and existing water bodies.

\section{(b) Reforestation area}

All protected forest areas in the land use potential map irrespective of the present land use, which have not been classified in category (a) - Protected area (i.e. all areas in present land use other than forest and water bodies) are first classified together. Further, all existing reforestation areas and encroached forest areas, irrespective of the potential land use are also categorized together. The aims of this land use zone could be related to both environmental conservation dimension and the economic dimension of land policy.

\section{(c) Intensive paddy cultivation area}

All areas for which the potential land use is paddy, and for which the present land use is irrigated land, paddy, field crops, fruits \& trees crop areas, pasture and grass land, and barren land are classified together.

\section{(d) Intensive field crops and tree crop cultivation area}

All field crops and tree crop areas in the potential land use map in which the present land use is irrigated land, paddy, field crops, fruit \& tree areas, pasture and grass land, and barren land are classified in this category.

\section{(e) Land area for development}

As seen from Table 4, all remaining land use categories in the overlay, where there is a mismatch between existing land use and potential land use are classified together. The area under this category is the potential area for diversion to nonagricultural uses like industry or community development, as area categories (a) and (b) are primarily areas for forestry conservation and development respectively, while area categories (c) and (d) are prime agricultural cultivation areas.

\section{Environmental planning}

Depletion of forest resources, deterioration of soil quality and fertility loss, and shortages in water supply are some typical manifestations of improper management of natural resources. Sound 
regional planning calls for sustainable development strategies which in turn means that environmental concerns need to be an integral part of the planning process itself. GIS is a very helpful tool in this regard. Identification of sensitive environmental areas like national forest areas and parks, encroached forest areas, reforestation areas, problem soil (saline and sodic, sandy, skeletal etc.) areas, erosion prone areas, location of mining and industrial sites, location of tourist areas, location of areas of potential occurrence of environmental hazards like drought, flooding, landslides etc., are easily carried out using a GIS and incorporated into the regional development plan. GIS was used for environmental management of problem soils and erosion hazard soils as follows:

\section{Data preparation}

Problem soil groups were re-classified from a general regional soil map into the broad general categories of acid sulphate soils, saline soils, sandy soils and skeletal soils. This was digitized and brought into the GIS database. Erosion hazard soils were identified based on the criteria of surface runoff from a general regional soil map, digitized and incorporated into the database. Present landuse data was the same as that used for landuse planning.

GIS procedure

Present landuse was overlaid over the problem soil layer and erosion hazard layer in turn to identify and formulate projects and countermeasures in vulnerable landuse categories. Overlay and Select were the main GIS operations.

\section{APPLICABILITY OF GIS AND ITS VALUE Criteria for GIS Implementation}

It is important to understand that GIS database design and analysis procedures largely depend on the kind of data available. Only when this is known can clear procedures regarding the data automation needs and type of GIS analysis necessary be determined. The availability of considerable analytical or theme maps in case of the Thailand project greatly facilitated in reducing the data automation needs and GIS processing whereas all analysis was performed from base maps in the Kenya Study. The choice of a PC based system in case of the Thailand project was found to be sufficient in spite of the large size of the spatial database. Workstation based systems were applied in the Kenya study to preclude any limitations due to hardware and software in database creation and analysis. Nevertheless, in both cases, the GIS implementation was possible. It is however very important to ensure portability and transferability of data to different platforms and systems from the host GIS database.

\section{Information Management Tool}

Use of GIS resulted in considerable savings in man hours. By conventional methods in which maps are prepared and overlaid manually and traced, it would take nearly 10 times the effort as compared to the GIS approach. The costs of installing a computer system, editing maps and training personnel are high in the GIS approach. But these are justifiable when considered against the number of iterations made possible by the use of GIS for the analysis in regional development planning studies. Further, GIS is also very useful to store and manage the digital database in an organized fashion throughout the project. GIS also enables us to do analyses not possible in any other way.

\section{Value of GIS Database}

One of biggest hurdles to implementing a GIS is the time and money required to prepare the base maps digitally. Their order of magnitude is very high when compared with the normal costs of analysis and preparation of outputs using conventional approaches, which are only allowed for consultants in typical projects. Their value is justifiable only when the digital database will be used and maintained for a long period of time by the clients. These require investments and changes in the organization hosting the GIS. Thus, the first implementation of GIS in any project or country is not very easy. In such cases, the GIS must be designed after carefully considering all the long term needs of the client so that the GIS can be utilized even after the life of the project.

Expert Interaction and Educating Domain Experts about GIS

To effectively use GIS tools, knowledge on the installation, programming and operation of 
computer hardware and software are also essential. The abilities required can vary from that of a computer user to a system engineer or even an expert depending on the volume of data and needs in the analyses. The tasks also can vary from transfer of knowledge by lectures to continuous supervision during the design and implementation of the GIS. The domain experts can learn about GIS through the initial projects and in future apply GIS oriented approaches. It is the domain experts who determine the kind of analyses that need to be done which is translated into GIS terms by the GIS expert. GIS design and formulation requires close interaction between the domain experts and the GIS expert, and educating domain experts about GIS only improves this interaction and understanding.

Training and Technology Transfer

Creation of a database goes hand in hand with the training and transfer of GIS technology to planning agencies in the developing countries, who would ultimately be updating the created database and using it in the future. This aspect is very important and needs to be considered in the early stages when the decision to use GIS is being made.

\section{About the Authors:}

Dr. Seetharam, K. E., directs the implementation of GIS in development projects for Nippon Koei Co. Ltd., Japan.

Dr. Sundaram,R.V., is an environmental consultant working for Nippon Koei Co. Ltd., Japan.

\section{References}

1. Seetharam, K.E.(1992) GIS and Its Application in Urban and Regional Planning and Management, Mapping Awareness 92 Conference, 71-83, British Library Catalog, London.

2. Seetharam, K.E., et.,al,(1992) Experiences of GIS Implementation in Consulting Works in development projects, Papers of the Geographic Information Systems Association, 1, 60-63, Japan.

3. Sundaram, R.V.(1991) Environmental Impact Analysis of Multi-purpose Water Resources Development Projects and Geographic
Informations Systems, International Symposium on Environmental Change and $G I S$, Asahikawa, Japan.

4. Kenya, (1983) Farm Management Handbook of Kenya, Ministry of Agriculture, Kenya.

5. FAO,(1982) Report on the Agro-ecological Zones Project, Rome. 
Table 1 Value of GIS in Various Dimensions

\begin{tabular}{|c|c|c|c|c|c|c|c|}
\hline \multirow{3}{*}{$\begin{array}{r}\text { COMPLEXITY } \\
\text { Value of data } \\
\text { (layers, area) * }\end{array}$} & \multirow{2}{*}{\multicolumn{2}{|c|}{ IN SPATIAL ANALYSIS }} & \multicolumn{5}{|c|}{$\begin{array}{l}\text { SITUATIONS TO SELECT GIS BASED APPROACH } \\
\text { (Legend: GIS: Yes use GIS, } X: \text { No use Mamual Methods) }\end{array}$} \\
\hline & & & \multicolumn{5}{|c|}{ EVALUATION CRITERIA TO JUSTIFY GIS } \\
\hline & $\begin{array}{l}\text { Detail of Information } \\
\text { (scale, pixcl size) * }\end{array}$ & * & $\begin{array}{l}\text { Cost of Data } \\
\text { preparalion }\end{array}$ & $\begin{array}{c}\text { Time \& casiness } \\
\text { of } A \text { nalysis }\end{array}$ & $\begin{array}{c}\text { Value of } \\
\text { Final Output } \\
\end{array}$ & $\begin{array}{l}\text { Cost of } \\
\text { Software }\end{array}$ & $\begin{array}{l}\text { Cost of } \\
\text { Handware }\end{array}$ \\
\hline $\begin{array}{cc}\text { Small Area } & 1 \\
(\sim 100 \text { sq.km, } & 1 \\
\text { ward }) & 1 \\
\end{array}$ & $\begin{array}{l}\text { Less }(1: 250000) \\
\text { Medium }(1: 25000) \\
\text { More }(1: 2500)\end{array}$ & $\begin{array}{l}1 \\
2 \\
4\end{array}$ & $\begin{array}{c}\mathrm{X} \\
\mathrm{x} \\
\mathrm{GIS} \\
\end{array}$ & $\begin{array}{c}x \\
X \\
\text { GIS } \\
\end{array}$ & \begin{tabular}{|c|}
$\mathrm{X}$ \\
$\mathrm{GIS}$ \\
$\mathrm{GIS}$ \\
\end{tabular} & $\begin{array}{c}\mathrm{X} \\
\mathrm{X} \\
\mathrm{GIS} \\
\end{array}$ & $\begin{array}{l}\mathrm{X} \\
\mathrm{X} \\
\mathrm{X}\end{array}$ \\
\hline $\begin{array}{l}\text { Medium Area } \\
(\sim 1000 \text { sq.km, } \\
\text { city }) \\
\end{array}$ & $\begin{array}{l}\text { Less (1km grid) } \\
\text { Medium (100m grid) } \\
\text { More }(10 \mathrm{~m} \text { grid) }\end{array}$ & $\begin{array}{r}2 \\
4 \\
16 \\
\end{array}$ & $\begin{array}{c}X \\
X \\
\text { GIS }\end{array}$ & $\begin{array}{l}\text { GIS } \\
\text { GIS } \\
\text { GIS }\end{array}$ & $\begin{array}{c}\mathrm{x} \\
\text { GIS } \\
\mathrm{GIS} \\
\end{array}$ & $\begin{array}{c}\mathrm{X} \\
\text { GIS } \\
\text { GIS }\end{array}$ & $\begin{array}{r}x \\
x \\
\text { GIS } \\
\end{array}$ \\
\hline $\begin{array}{cc}\begin{array}{cc}\text { Large Area } \\
(\sim 100000 \text { sq.km, }\end{array} & 3 \\
\text { country }) & 3\end{array}$ & $\begin{array}{l}\text { Less Detail } \\
\text { Medium Detail } \\
\text { More Detail }\end{array}$ & $\begin{array}{r}3 \\
6 \\
36 \\
\end{array}$ & $\begin{array}{c}x \\
\text { GIS } \\
\text { GIS }\end{array}$ & $\begin{array}{l}\text { GIS } \\
\text { GIS } \\
\text { GIS }\end{array}$ & $\begin{array}{c}\mathrm{X} \\
\text { GIS } \\
\text { GIS }\end{array}$ & $\begin{array}{l}\text { GIS } \\
\text { GIS } \\
\text { GIS }\end{array}$ & $\begin{array}{l}\text { GIS } \\
\text { GIS } \\
\text { GIS }\end{array}$ \\
\hline
\end{tabular}

Note: * A relative ratio to express the complexity of spalial information. Information of less detail for a small area is considered as one unit.

Table 2 Salient Features of Projects

\begin{tabular}{|c|c|c|}
\hline \multirow[t]{2}{*}{ SALIENT FEATURE } & \multicolumn{2}{|l|}{ DESCRIPTION } \\
\hline & KENYA STUDY & THAIL,AND STUDY \\
\hline Area & 580,000 sq. km. & $90,000 \mathrm{sq} . \mathrm{km}$ \\
\hline $\begin{array}{l}\text { Database Contents } \\
\text { Size of Digital database }\end{array}$ & $\begin{array}{l}\text { Land and Water Resources Information } \\
\text { and base maps } \\
\text { over } 25 \text { laycrs with } 1500 \mathrm{MB} \text { of digital data }\end{array}$ & $\begin{array}{l}\text { Land based Natural Resources Information } \\
\text { over } 12 \text { layers with } 200 \mathrm{MB} \text { digital data }\end{array}$ \\
\hline $\begin{array}{l}\text { Major Applications } \\
\text { involving GIS analysis }\end{array}$ & $\begin{array}{l}\text { Land Suitability analysis for crops } \\
\text { Irrigation potential analysis from surface } \\
\text { water } \\
\text { Water demand analysis for Agriculture } \\
\text { Ground Water potential analysis for } \\
\text { Irrigation }\end{array}$ & $\begin{array}{l}\text { Landuse development zoning } \\
\text { Agricultural landuse planning for crops } \\
\text { Identifying irrigation projects } \\
\text { Problem soil and erosion hazard soil } \\
\text { management } \\
\text { Determination of surface runoffs for water } \\
\text { potential estimation }\end{array}$ \\
\hline Hardware/software & $\begin{array}{l}\text { Sun Sparc 2, Macintosh, 386PC } \\
\text { Arc/info, Oracle, Atlas GIS }\end{array}$ & $\begin{array}{l}486 \text { PC } \\
\text { AutoCad, pc-Arc/info, Spans, GEO/SQL }\end{array}$ \\
\hline $\begin{array}{l}\text { Typical GIS operations } \\
\text { Menu of output }\end{array}$ & $\begin{array}{l}\text { Overlay, Buffer, TIN, Query, DBMS link, } \\
\text { Import, Export } \\
\text { A0 Plots, A4 prints, Slides, Tables }\end{array}$ & $\begin{array}{l}\text { Ovcrlay, Qucry, Import, Export } \\
\text { A0 plots, A3 plots, Tables }\end{array}$ \\
\hline $\begin{array}{l}\text { Time frame (elapsed } \\
\text { time only) }\end{array}$ & $\begin{array}{l}\text { Total 8: } 3 \text { months for data input, } 2 \text { month } \\
\text { for analysis, } 3 \text { months for output } \\
\text { generation }\end{array}$ & $\begin{array}{l}\text { Total } 8: 3 \text { months for data automation and } \\
\text { design and } 5 \text { months for GIS analysis and } \\
\text { output generation }\end{array}$ \\
\hline
\end{tabular}


Table 3 List of Data in the GIS Database for the Study

\begin{tabular}{|c|c|c|c|c|}
\hline \begin{tabular}{|l} 
DATA \\
\end{tabular} & KENYA & STUDY & THAILAND & STUDY \\
\hline Data Description & Information on Data & Approach for Data input & Information on Data & Approach for Data input \\
\hline $\begin{array}{l}\text { Socioeconomy } \\
\text { Population } \\
\text { Industry }\end{array}$ & $\begin{array}{l}\text { Tables } \\
\text { Tables }\end{array}$ & Tabular input & & Tabular input \\
\hline $\begin{array}{l}\text { Meteorology } \\
\text { Rainfall } \\
\text { Temperature } \\
\text { Humidity } \\
\text { Hydrography }\end{array}$ & $\begin{array}{l}1: 5000000 \\
1: 5000000 \\
1: 5000000\end{array}$ & Digitizing & $\begin{array}{l}1: 1000000 \\
1: 250000 \\
\end{array}$ & Digitizing \\
\hline $\begin{array}{l}\text { Natural Resources } \\
\text { National Parks } \\
\text { Forests } \\
\text { Landuse } \\
\text { Soil } \\
\text { Land Suitability } \\
\text { Soil Salinity } \\
\end{array}$ & $\begin{array}{l}1: 2000000 \\
1: 2000000 \\
1: 1000000 \\
1: 1000000\end{array}$ & Digitizing & $\begin{array}{l}1: 1000000 \\
1: 100000 \\
1: 500000 \\
1: 250000 \\
1: 250000 \\
\end{array}$ & Digitizing \\
\hline $\begin{array}{l}\text { Topography } \\
\text { Contours } \\
\text { Roads }\end{array}$ & $\begin{array}{l}1: 100000 \\
1: 1000000 \\
\end{array}$ & Digitizing & $\begin{array}{l}1: 250000 \\
1: 250000 \\
\end{array}$ & Digitizing \\
\hline $\begin{array}{l}\text { Water Resources } \\
\text { Rivers } \\
\text { Basin Boundary }\end{array}$ & $\begin{array}{l}1: 2000000 \\
1: 2000000 \\
\end{array}$ & Digitizing & $\begin{array}{l}1: 250000 \\
1: 1000000 \\
\end{array}$ & Digitizing \\
\hline $\begin{array}{l}\text { Georeference } \\
\text { Cities } \\
\text { Administrative } \\
\text { boundary }\end{array}$ & $\begin{array}{l}1: 100000 \\
1: 100000\end{array}$ & Digitizing & $1: 100000$ & Digitizing \\
\hline $\begin{array}{l}\text { Groundwater } \\
\text { Borehole } \\
\text { Water Quality }\end{array}$ & $\begin{array}{l}\text { Tables } \\
\text { Tables } \\
\end{array}$ & Automatic data transfer & & \\
\hline Geology & $1: 1000000$ & Digitizing & & \\
\hline Landcover & $\begin{array}{l}\text { LANDSAT, } \\
\text { NOAA,SPOT }\end{array}$ & $\begin{array}{l}\text { Image processing } \\
\text { Raster to vector } \\
\text { conversion }\end{array}$ & LANDSAT & $\begin{array}{l}\text { Image Processing } \\
\text { Manual Digitizing }\end{array}$ \\
\hline & & & $1: 1000000$ & Digitizing \\
\hline
\end{tabular}

Table 4 Land Use Zoning Procedure

\begin{tabular}{|c|c|c|c|c|c|c|c|c|c|c|c|c|c|}
\hline Plan & $\begin{array}{l}\text { Present Landuse } \\
\text { ed Land Use }\end{array}$ & $\begin{array}{l}\text { Irrigated } \\
\text { Land }\end{array}$ & Pakkly & $\begin{array}{l}\text { Field } \\
\text { Crops }\end{array}$ & $\begin{array}{c}\text { Fruit and } \\
\text { Tree } \\
\text { Arcas }\end{array}$ & $\begin{array}{l}\text { Pasture } \\
\text { and } \\
\text { Grass } \\
\text { Land } \\
\end{array}$ & Forest & $\mid \begin{array}{c}\text { Reforesta } \\
\text { tion } \\
\text { Areas }\end{array}$ & $\begin{array}{c}\text { Encroach } \\
\text { od } \\
\text { Forests }\end{array}$ & $\begin{array}{l}\text { Walcr } \\
\text { Bodies }\end{array}$ & $\begin{array}{l}\text { Barren } \\
\text { Land }\end{array}$ & $\begin{array}{l}\text { Mixed } \\
\text { Paddy } \\
\text { and } \\
\text { Forest }\end{array}$ & $\begin{array}{l}\text { Mixed } \\
\text { field } \\
\text { crop and } \\
\text { forest }\end{array}$ \\
\hline 1.1 & Protected Forests & b & b & $b$ & b & b & $\mathbf{a}$ & b & b & $\mathbf{a}$ & b & b & b \\
\hline 2.1 & Paddy & c & c & c & c & c & $\mathbf{a}$ & b & b & a & c & e & e \\
\hline 2.2 & $\begin{array}{l}\text { Ficld Crops and Trce } \\
\text { Crops }\end{array}$ & d & d & d & d & d & $\mathbf{a}$ & b & b & $\mathbf{a}$ & d & e & e \\
\hline 2.3 & $\begin{array}{l}\text { Unsuitable for } \\
\text { Cultivation but can } \\
\text { be Pasture/Livestock } \\
\text { Grazing Area or } \\
\text { Wood Land }\end{array}$ & e & e & $\mathrm{e}$ & e & e & $\mathbf{a}$ & b & b & $\mathbf{a}$ & $\mathbf{e}$ & e & e \\
\hline
\end{tabular}

Legend: (a) Protected Area, (b) Reforcstation Arca, (c) Intensive Paddy Cultivation Area, (d) Intensive Ficld Crop and Tree Crop Cultivation Area, (c) Land Arca for Development 